\title{
PENGARUH HOUSE INDEX DAN MAYA INDEX TERHADAP KEJADIAN DEMAM BERDARAH DENGUE DI KECAMATAN GROGOL KABUPATEN SUKOHARJO MENGGUNAKAN GEOGRAPHIC INFORMATION SYSTEM (GIS)
}

\section{The Effect of Index and Maya Index House on The Event of Dengue Blood Fever in Grogol District, Sukoharjo District Using Geographic Information System (GIS)}

\author{
${ }^{1}$ Nine Elissa Maharani, 2 Pranichayudha Rohsulina \\ ${ }^{1}$ Staf Pengajar Bagian Kesehatan Lingkungan Fakultas Kesehatan Masyarakat \\ ${ }^{2}$ Staf Pengajar Program Studi Geografi Fakultas Keguruan dan Ilmu Pendidikan \\ Universitas Veteran Bangun Nusantara Sukoharjo \\ Email : elissapanjimomo@gmail.com
}

\begin{abstract}
Dengue fever is an important public health problem in indonesia, in the year 2014 the number of death due to dengue fever in Indonesia 903 people from 99499 cases. Sukoharjo district is one of the bloody endemic distrric in central java. In eradicating dengue fever, the larva survey used is a visual method using the entomology indicator, the house index and maya index. This study aims to determine the effect of house index and maya index on the incidence of dengue fever in Grogol district of Sukoharjo using geographic information system (GIS). The research method used is an analytical survey wuth cross sectional approach. The result of the study showed a maya index effect on the incidence of dengue fever in Grogol district of Sukoharjo (p value 0,00), there is no effect of house index on the incidence of dengue fever in Grogol District of Sukoharjo ( $p$ value 0,87).
\end{abstract}

Keyword : House index, Maya index, DBD, SIG

\begin{abstract}
Abstrak
Penyakit DBD merupakan salah satu masalah kesehatan masyarakat penting yang ada di Indonesia. Tahun 2014 jumlah kasus meninggal akibat DBD di Indonesia sebanyak 903 orang dari 99.499 kasus. Kabupaten Sukoharjo merupakan salah satu Kabupaten endemis demam berdarah yang ada di Jawa Tengah. Dalam pemberantasan DBD, survey jentik yang digunakan adalah cara visual menggunakan indikator entomologi yaitu House Index dan Maya Index. Penelitian ini bertujuan mengetahui pengaruh house index dan maya index terhadap kejadian DBD di Kecamatan Grogol Kabupaten Sukoharjo menggunakan Sistem Informasi Geografis (GIS). Metode penelitian yang digunakan adalah survey analitik dengan pendekatan cross sectional. Hasil penelitian menunjukkan ada pengaruh maya index terhadap kejadian DBD di Kecamatan Grogol Kabupaten Sukoharjo (p value 0,00), tidak ada pengaruh house index terhadap kejadian DBD di Kecamatan Grogol Kabupaten Sukoharjo ( $p$ value 0,87 ).
\end{abstract}

Kata Kunci : House index, Maya index, DBD, SIG

${ }^{1}$ Nine Elissa Maharani adalah Staf Pengajar Bagian Kesehatan Lingkungan Fakultas Kesehatan Masyarakat Universitas Veteran Bangun Nusantara Sukoharjo

2 Pranichayudha Rohsulina adalah Staf Pengajar Program Studi Geografi Fakultas Keguruan dan Ilmu PendidikanUniversitas Veteran Bangun Nusantara Sukoharjo 


\section{PENDAHULUAN}

Penyakit demam berdarah dengue adalah penyakit menular yang disebabkan virus dengue dan ditularkan oleh nyamuk Aedes aegypti. (Depkes RI,2008). Penyakit DBD merupakan salah satu masalah kesehatan masyarakat penting yang ada di Indonesia. Penyakit ini sering ditemukan di daerah tropis dan sub tropis dan Asia menempati urutan pertama dalam jumlah kasus DBD setiap tahunnya. Indonesia menduduki peringkat kedua DBD setelah Brazil. Jumlah mortalitas akibat DBD mencapai 1.125 kasus pada tahun 2009-2011. Tahun 2013 jumlah mortalitas akibat DBD sebanyak 871 orang dari 112.511 kasus DBD. (Kemenkes RI, 2010).

Jumlah kasus DBD di Jawa Tengah tahun 2014 sebanyak 11.081. Kabupaten Sukoharjo merupakan salah satu Kabupaten endemis demam berdarah yang ada di Jawa Tengah. Setiap tahun selalu ada kasus demam berdarah di kabupaten ini. Kabupaten Sukoharjo terdiri dari 12 kecamatan. Salah satunya adalah kecamatan Grogol yang berada di bagian kota. Jumlah kasus DBD di kecamatan Grogol tahun 2016 mencapai 152 kasus DBD. Fogging sebagai upaya pemerintah untuk mencegah DBD telah dilakukan, tetapi sampai saai ini kasus DBD selalu muncul di kecamatan ini.

Dalam pemberantasan DBD, survey jentik yang digunakan adalah cara visual menggunakan indikator entomologi yaitu House Index dan Maya Index. House Index adalah jumlah rumah dimana ditemukan sarang Aedes, sedangkan MI adalah indikator yang digunakan untuk mengidentifikasi area risiko tinggi sebagai tempat perkembangbiakan nyamuk Aedes yang didasarkan pada kebersihan area dan ketersediaan tempat yang berpotensi untuk perkembangbiakan Aedes.

Salah satu cara yang efektif dan masih tergolong jarang dilakukan untuk pencegahan dan pengendalian kasus DBD adalah dengan analisis spasial menggunakan program Geographic Information System (GIS). Program ini dapat digunakan untuk memetakkan penyakit sehingga mampu menidentifikasi daerah yang beresiko tinggi. Program ini mampu digunakan untuk melakukan perencanaan yang lebih baik dalam pemberantasan dan pencegahan penyakit. (Peristiowati, 2014).

\section{METODE}

Jenis penelitian ini adalah survey analitik, yaitu penelitian yang mencoba menggali bagaimana dan mengapa fenomena kesehatan itu terjadi, kemudian melakukan analisis dinamika korelasi antara faktor risiko dengan faktor efek. (Riyanto, 2010). Penelitian ini menggunakan desain rancangan cross sectional (point of approach) yaitu pengukuran atau pengamatan antara faktor risiko dan faktor efek dilakukan pada saat bersamaan (sekali waktu) (Riyanto, 2010). Analisis data yang digunakan menggunakan :

1. Analisis Univariat

Digunakan untuk menganalisis tiap-tiap variabel yang akan diukur yang meliputi variabel bebas, variabel terikat dan karakteristik responden menggunakan distribusi frekuensi kemudian dinarasikan.

\section{Analisis Bivariat}

Analisis bivariat menggunakan uji statistik Chi Square dengan $\alpha 5 \%$. Kriteria pengujian : jika p value $<\alpha 5 \%$, maka Ho ditolak (ada pengaruh 
signifikan). Jika $\mathrm{p}$ value $\geq \alpha 5 \%$, maka Ho diterima (tidak ada pengaruh signifikan)
3. Analisis Spasial

Aplikasi ArcView GIS digunakan untuk mapping pemetaan kasus DBD.

\section{HASIL PENELITIAN DAN PEMBAHASAN}

\section{Analisis Univariat}

Tabel 1. Distribusi Kejadian DBD di Kecamatan Grogol Kabupaten Sukoharjo

\begin{tabular}{llrr}
\hline No. & Kejadian DBD & Frekuensi & Persentase (\%) \\
\hline 1. & DD & 60 & 39,5 \\
2. & DBD & 84 & 55,3 \\
3. & DSS & 8 & 5,3 \\
\hline & Jumlah & 152 & 100 \\
\hline
\end{tabular}

Berdasarkan tabel 3 di atas menunjukkan bahwa kejadian Demam Berdarah Dengue di Kecamatan Grogol Kabupaten Sukoharjo sebagian besar masuk dalam kategori DBD sebesar
55,3\%. Distribusi kasus/ kejadian DBD di desa yang ada di Kecamatan Grogol Kabupaten Sukoharjo dapat diketahui dari tabel 2.

Tabel 2. Distribusi Kasus/Kejadian DBD di desa di Kecamatan Grogol Kabupaten Sukoharjo

\begin{tabular}{|c|l|c|c|}
\hline No. & \multicolumn{1}{|c|}{ Desa } & Frekuensi & Persentase (\%) \\
\hline 1 & Langenharjo & 20 & 13,2 \\
\hline 2 & Parangjoro & 6 & 3,9 \\
\hline 3 & Pandeyan & 6 & 3,9 \\
\hline 4 & Kadokan & 5 & 3,3 \\
\hline 5 & Pondok & 4 & 2,6 \\
\hline 6 & Grogol & 16 & 10,5 \\
\hline 7 & Madegondo & 10 & 6,6 \\
\hline 8 & Telukan & 7 & 15,8 \\
\hline 9 & Kwarasan & 6 & 4,6 \\
\hline 10 & Gedangan & 3 & 3,9 \\
\hline 11 & Manang & 14 & 2,0 \\
\hline 12 & Sanggrahan & 5 & 9,2 \\
\hline 13 & Banaran & 26 & 3,3 \\
\hline 14 & Cemani & $\mathbf{1 5 2}$ & 17,1 \\
\hline & Jumlah & & $\mathbf{1 0 0}$ \\
\hline
\end{tabular}

Berdasarkan tabel 2 dia atas menunjukkan bahwa distribusi kasus DBD yang ada di
Cemani yaitu sebanyak 26 kasus $(17,1)$ dari 152 kasus. Jumlah kasus paling sedikit terdapat pada desa Manang yaitu 3 kasus (2,0\%) dari 152 kasus. 
a. House Index

Tabel 3. Distribusi frekuensi House Index di Kecamatan Grogol Kabupaten Sukoharjo

\begin{tabular}{clrr}
\hline No. & \multicolumn{1}{c}{ House Index } & Frekuensi & Persentase (\%) \\
\hline 1 & Rendah & 3 & 2 \\
2 & Tinggi & 149 & 98 \\
\hline & Jumlah & $\mathbf{1 5 2}$ & $\mathbf{1 0 0}$ \\
\hline
\end{tabular}

Berdasarkan tabel 3 di atas dapat diketahui bahwa house index di Kecamatan Grogol Kabupaten Sukoharjo sebagian besar masuk dalam kategori tinggi yaitu sebesar 149 (98\%).
Distribusi House Index di desa yang ada di Kecamatan Nguter dapat dilihat pada tabel di bawah ini.

Tabel 4. Distribusi House Index DBD di desa yang ada di Kecmatan Grogol Kabupaten Sukoharjo

\begin{tabular}{clcc}
\hline No. & \multicolumn{1}{c}{ Desa } & House Index & Kategori \\
\hline 1. & Langenharjo & 25 & Tinggi \\
2. & Parangjoho & 33 & Tinggi \\
3. & Pandeyan & 33 & Tinggi \\
4 & Kadokan & 40 & Tinggi \\
5 & Pondok & 50 & Tinggi \\
6. & Grogol & 25 & Tinggi \\
7. & Madegondo & 30 & Tinggi \\
8. & Telukan & 25 & Tinggi \\
9. & Kwarasan & 28 & Tinggi \\
10. & Gedangan & 50 & Tinggi \\
11. & Manang & 0 & Rendah \\
12. & Sanggrahan & 21 & Tinggi \\
13. & Banaran & 40 & Tinggi \\
14. & Cemani & 27 & Tinggi \\
\hline
\end{tabular}

Berdasarkan tabel 4 di atas diketahui bahwa sebagian besar house index yang ada di desa yang ada di Kecamatan
Grogol masuk kategori tinggi. Hanya ada 1 desa di Kecamatan Grogol yang masuk dalam kategori rendah.

\begin{tabular}{llccc}
\hline \multirow{2}{*}{ Kategori } & \multirow{2}{*}{ Jenis } & Jumlah & $\begin{array}{c}\text { Positif larva } \\
\mathbf{( + )}\end{array}$ & $\begin{array}{c}\text { Persentase } \\
\mathbf{( \% )}\end{array}$ \\
\cline { 3 - 5 } & & 15 & 3 & 20 \\
\hline DS & Ban bekas & 26 & 2 & 7,7 \\
& Tempayan & 6 & 2 & 33,3 \\
& Drum & 87 & 15 & 17,2 \\
& Pecahan botol & 69 & 12 & 17,4 \\
& Kaleng bekas & 4 & 3 & 75 \\
\hline & Bak mandi & $\mathbf{2 0 7}$ & $\mathbf{3 7}$ & $\mathbf{1 7 , 9}$ \\
\hline
\end{tabular}




\begin{tabular}{llccc}
\hline \multirow{2}{*}{ Kategori } & Jenis & Jumlah & $\begin{array}{c}\text { Positif larva } \\
\mathbf{( + )}\end{array}$ & $\begin{array}{c}\text { Persentase } \\
\text { (\%) }\end{array}$ \\
\cline { 3 - 5 } & & 160 & 62 & 38,8 \\
\hline CS & Bak mandi & 11 & 2 & 18,2 \\
& Tempayan & 5 & 1 & 20,0 \\
& Drum & 7 & 1 & 14,3 \\
\hline & Lain-lain & $\mathbf{1 8 3}$ & $\mathbf{6 6}$ & $\mathbf{3 6 , 1}$ \\
\hline & Total CS & $\mathbf{3 9 0}$ & $\mathbf{1 0 3}$ & $\mathbf{2 6 , 4 1}$ \\
\hline
\end{tabular}

Berdasarkan tabel di atas diketahui bahwa jumlah DS adalah 207 buah dan sebanyak $37(17,9 \%)$ diketahui positif larva Aedes aegypty. Jumlah CS berdasarkan tabel 4 di atas adalah 183 buah dan $66(36,1 \%)$ ditemukan positif larva Aedes sp.

Tabel 5. Distribusi rumah berdasarkan kategori BRI dan HRI Kecamatan Grogol Kabupaten Sukoharjo

\begin{tabular}{lrrrr}
\hline \multirow{2}{*}{ Kategori } & \multicolumn{2}{c}{ BRI } & \multicolumn{2}{c}{ HRI } \\
\cline { 2 - 6 } & $\mathrm{N}$ & $\%$ & $\mathrm{~N}$ & $\%$ \\
\hline Tinggi & 0 & 0 & 32 & 21,1 \\
Sedang & 23 & 15,1 & 58 & 38,2 \\
Rendah & 129 & 84,9 & 62 & 40,8 \\
\hline Jumlah & 152 & 100 & 152 & 100 \\
\hline
\end{tabular}

Berdasarkan tabel 5 di atas dapat disimpulkan bahwa nilai BRI sebagian besar di Kecamatan Grogol masuk dalam kategori rendah sebanyak 84,9 \% dan nilai HRI sebagian besar masuk dalam kategori rendah sebesar 40,8\%.
Distribusi Maya Index per desa di Kecamatan Grogol Kabupaten Sukoharjo dapat diketahui dari table 6 di bawah ini.

\begin{tabular}{clcc}
\hline No. & Desa & $\begin{array}{c}\text { Rerata Nilai } \\
\text { Maya Index }\end{array}$ & Kategori \\
\hline 1. & Langenharjo & 1,47 & Sedang \\
2 & Parangjoro & 1,56 & Rendah \\
3 & Pandeyan & 1,47 & Sedang \\
4 & Kadokan & 1,56 & Rendah \\
5 & Pondok & 1,56 & Rendah \\
6 & Grogol & 1,47 & Sedang \\
7 & Madegondo & 1,56 & Rendah \\
8 & Telukan & 1,56 & Rendah \\
9 & Kwarasan & 1,56 & Rendah \\
10 & Gedangan & 1,56 & Rendah \\
11 & Manang & 1,56 & Rendah \\
12 & Sanggrahan & 1,56 & Rendah \\
13 & Banaran & 1,56 & Rendah \\
\hline
\end{tabular}




\begin{tabular}{cccc}
\hline No. & Desa & $\begin{array}{c}\text { Rerata Nilai } \\
\text { Maya Index }\end{array}$ & Kategori \\
\hline 14 & Cemani & 1,56 & Rendah \\
\hline & & & \\
\hline No. & Maya Index & Frekuensi & Persentase (\%) \\
\hline 1. & Tinggi & 7 & 4,6 \\
2. & Sedang & 33 & 21,7 \\
3. & Rendah & 112 & 73,7 \\
\hline & Jumlah & $\mathbf{1 5 2}$ & $\mathbf{1 0 0}$ \\
\hline
\end{tabular}

Berdasarkan tabel 7 di atas bahwa maya index yang ada di kecamatan grogol kabupaten sukoharjo masuk dalam kategori rendah yaitu sebanyak 73,7\%.

Analisis Bivariat

a. Pengaruh House Index terhadap Kejadian DBD di Kecamatan Grogol Kabupaten Sukoharjo

Tabel 8. Crosstab house index dengan kejadian DBD di Kecamatan Grogol Sukoharjo

\begin{tabular}{|c|c|c|c|c|c|c|c|c|}
\hline \multirow{3}{*}{$\begin{array}{l}\text { House } \\
\text { index }\end{array}$} & \multicolumn{6}{|c|}{ Kejadian DBD } & \multicolumn{2}{|c|}{ Total } \\
\hline & \multicolumn{2}{|c|}{ DSS } & \multicolumn{2}{|c|}{ DBD } & \multicolumn{2}{|c|}{ DD } & & \multirow[b]{2}{*}{$\%$} \\
\hline & $\mathbf{N}$ & $\%$ & $\mathbf{n}$ & $\%$ & $\mathbf{N}$ & $\%$ & & \\
\hline Tinggi & 8 & 5,4 & 82 & 55 & 59 & 39,6 & 149 & 100 \\
\hline Rendah & 0 & 0 & 2 & 66,7 & 1 & 33,3 & 3 & 100 \\
\hline Total & 8 & 5,3 & 84 & 55,3 & 60 & 39,5 & 152 & 100 \\
\hline \multicolumn{9}{|c|}{$P$ value $=0,87$} \\
\hline
\end{tabular}

Berdasarkan tabel 8 di atas dapat diketahui bahwa kejadian DBD di Kecamatan Grogol Kabupaten Sukoharjo sebagian besar terjadi di rumah dengan kategori house index tinggi sebesar 55\%. Dari hasil uji statistik dapat diketahui nilai $\mathrm{p}$ value $0,87>0,05$ sehingga menunjukkan tidak ada pengaruh signifikan house index dengan kejadian DBD di Kecamatan Grogol Kabupaten Sukoharjo.

Menurut Scott and Morisson,2002 house index merupakan salah satu indikator yang digunakan untuk menghitung risiko penyebaran penyakit. Index ini memberikan petunjuk tentang persentase rumah yang positif untuk perkembangiakan dan juga menunjukkan populasi manusia yang berisiko terkena DBD.

Penelitian Hutagalung,2009 menunjukkan bahwa faktor risiko dengue dipengaruhi oleh tidak adanya aktivitas PSN $(\mathrm{OR}=4,8)$ dan tempat yang disukai oleh jentik nyamuk adalah bak mandi, barang bekas dan ban bekas. 
Tabel 9. Crosstab Maya Index dengan Kejadian DBD di Kecamatan Grogol Kabupaten Sukoharjo

\begin{tabular}{|c|c|c|c|c|c|c|c|c|}
\hline \multirow{3}{*}{$\begin{array}{l}\text { Maya } \\
\text { index }\end{array}$} & \multicolumn{6}{|c|}{ Kejadian DBD } & \multicolumn{2}{|c|}{ Total } \\
\hline & \multicolumn{2}{|c|}{ DSS } & \multicolumn{2}{|c|}{ DBD } & \multicolumn{2}{|c|}{ DD } & & \\
\hline & $\mathrm{N}$ & $\%$ & $\mathrm{n}$ & $\%$ & $\mathrm{~N}$ & $\%$ & & $\%$ \\
\hline Tinggi & 4 & 57,1 & 3 & 42,9 & 0 & 0 & 7 & 100 \\
\hline Sedang & 1 & 3 & 32 & 97 & 0 & 0 & 33 & 100 \\
\hline Rendah & 3 & 2,7 & 49 & 43,8 & 60 & 53,6 & 112 & 100 \\
\hline Total & 8 & 5,3 & 84 & 55,3 & 60 & 39,5 & 152 & 100 \\
\hline
\end{tabular}

Berdasarkan tabel 9 di atas dapat disimpulkan bahwa kejadian DSS di Kecamatan Grogol Kabupaten Sukoharjo sebagian besar terjadi pada rumah dengan kategori maya index tinggi yaitu sebesar $57,1 \%$. Nilai $\mathrm{p}$ value $=0,00$ artinya Ha diterima dan Ho ditolak sehingga menunjukkan ada pengaruh antara maya index dengan kejadia DBD di Kecamatan Grogol Kabupaten Sukoharjo.

Kondisi tempat potensial perkembangbiakan nyamuk Aedes aegypty dapat diketahui dengan menggunakan indikator maya index. Maya index juga digunakan sebagai upaya pengendalian DBD di suatu daerah karena dapat diketahui tingkat risiko dan tempat perkembangbiakan yang paling disukai, sehingga berguna menentukan prioritas dalam penyusunan program pengendalian jentik nyamuk. Maya index diperoleh dari kombinasi 2 indikator utama yaitu BRI dan HRI. Berdasarkan data hasil penelitian bahwa ada pengaruh antara maya index dengan kejadian DBD di Kecamatan Grogol Kabupaten Sukoharjo Status maya index yang tinggi menunjukkan rumah kasus berisiko tinggi sebagai tempat perkembangbiakan nyamuk Aedes. Hasil penelitian menunjukkan nilai HRI terbanyak kategori rendah sebanyak
40,8\%. Hal ini dapat diartikan bahwa jumlah DS yang rendah dan masuk dalam kategori bersih, sedangkan jumah DS yang tinggi dan dikategorikan kotor sebanyak 32 rumah (21,1\%). Jadi semakin tinggi nilai HRI maka dapat disimpulkan rumah semakin kotor. HRI menggambarkan kebersihan rumah. Nilai $p$ value hasil penelitian 0,014 artinya ada pengaruh maya index dengan kejadian DBD di Kecamatan Grogol Kabupaten Sukoharjo. Menurut Sugito pada musim penularan hanya beberapa nyamuk saja yang berubah menjadi vektor. Nyamuk akan berubah menjadi vektor jika ada orang sakit sebagai sumber penularan.

Hasil penelitian ini sejalan dengan penelitian Sang. G, 2010 yang menyatakan bahwa ada hubungan status maya index dengan kejadian DBD ( $p$ value 0,014). Dari hasil penelitian menunjuukan bahwa jumlah DS lebih sedikit jika dibanding dengan jumlah CS, hal ini dikarenakan pada saat penelitian tidak terjadi pada musim penghujan. Disposable Sites menunjukkan jumlah tempat penampungan air yang tidak bisa dikontrol yang berupa sampah yang terdapat di luar rumah dan merupakan tempat perkembangbiakan nyamuk Aedes aegypty. 
Sebaran kasus House Index Kecamatan Grogol Kabupaten Sukoharjo

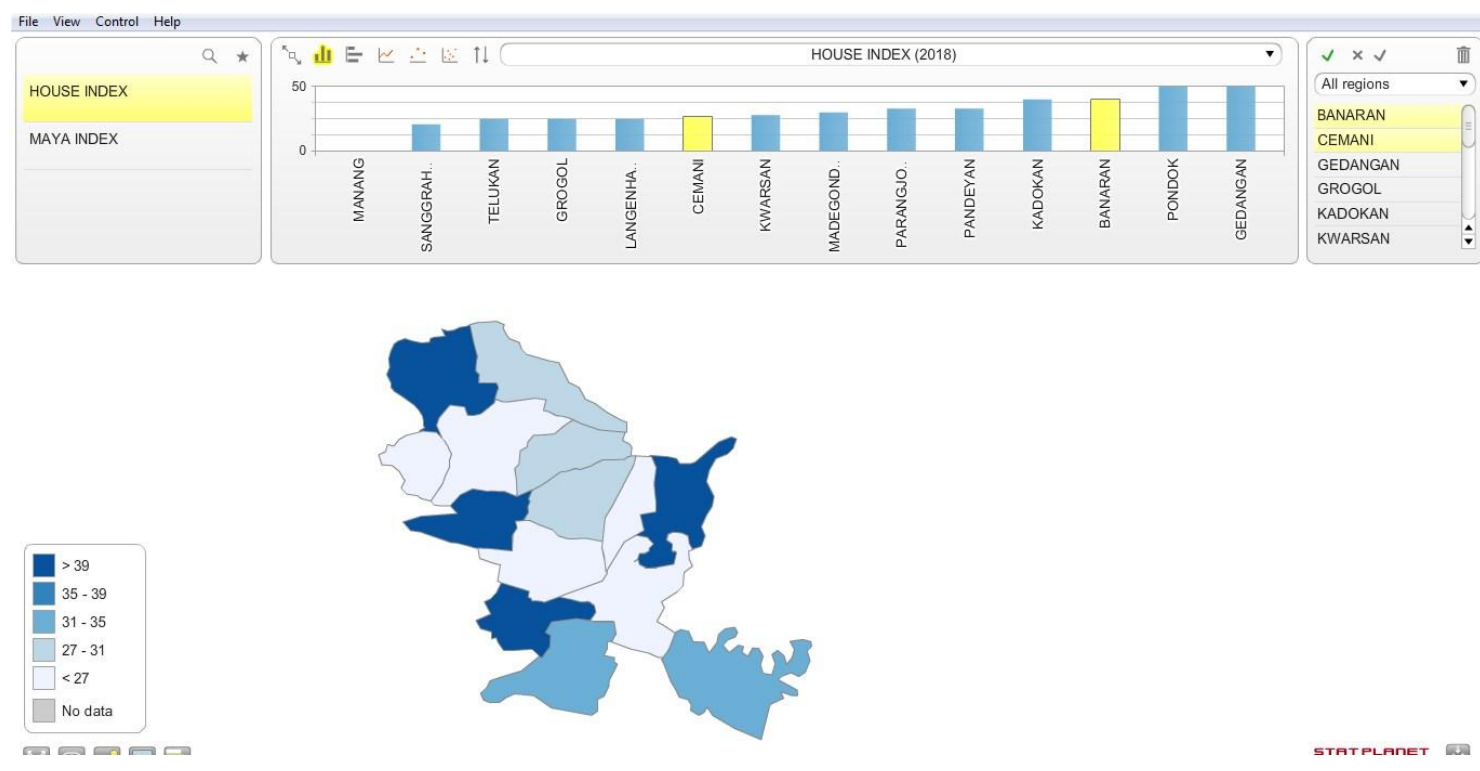

Sebaran kasus Maya Index Kecamatan Grogol Kabupaten Sukoharjo
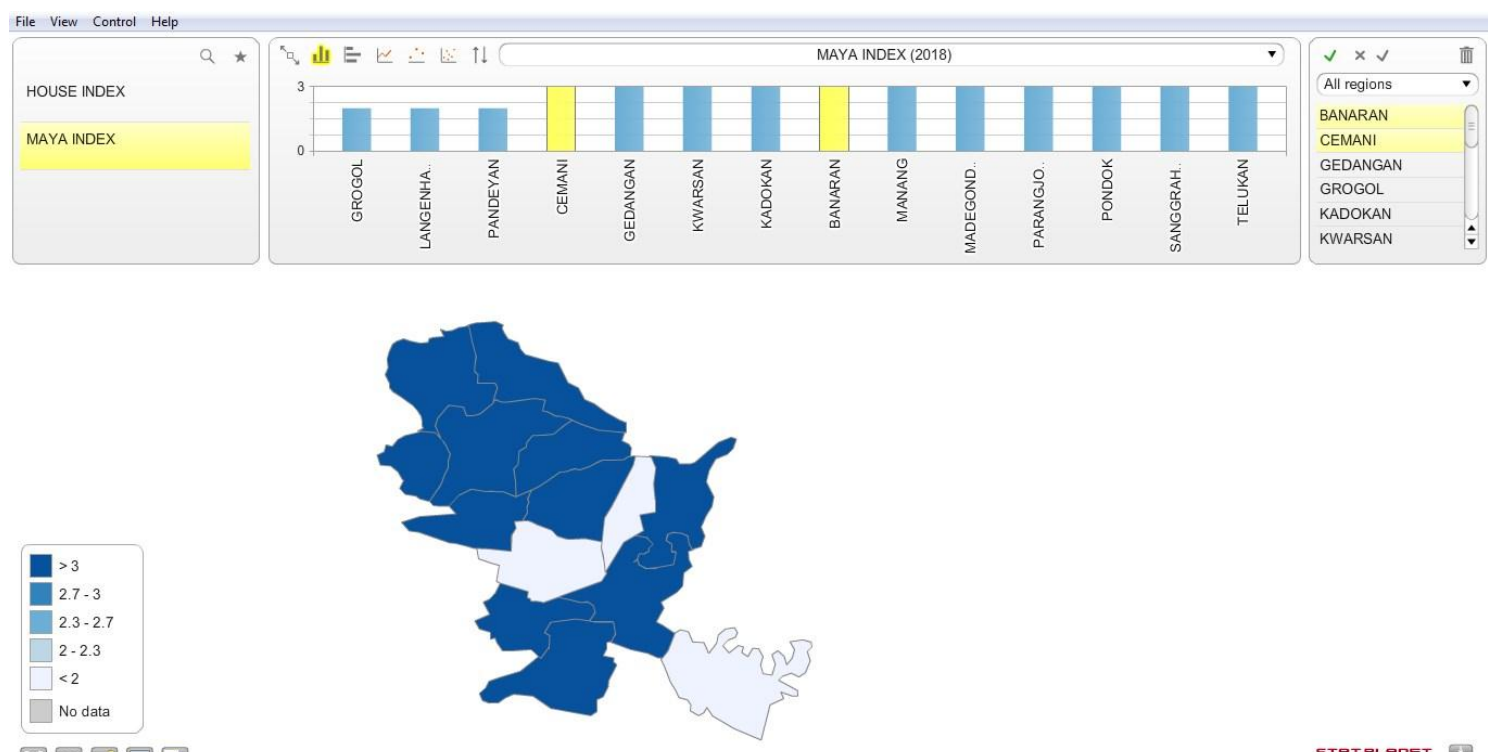

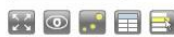

\section{SIMPULAN DAN SARAN}

Simpulan

1. Tidak ada pengaruh house index dengan kejadian DBD di Kecamatan Grogol Kabupaten Sukoharjo (p value 0,87 )
2. Ada pengaruh maya index dengan kejadian DBD di Kecamatan Grogol Kabupaten Sukoharjo ( $\mathrm{p}$ value $=$ $0,00)$ 
Saran

1. Bagi Instansi Kesehatan

Memberikan program fogging untuk memutus mata rantai penularan DBD di Kecamatan Grogol Kabupaten Sukoharjo.

2. Bagi Masyarakat Meningkatkan gerakan pemberantasan sarang nyamuk baik di dalam lingkungan rumah maupun di luar lingkungan rumah melalui 3M Plus

\section{DAFTAR RUJUKAN}

[1] Danuedono,Projo. 1997. Pemodelan Spasial Untuk Kajian Kesehatan (Kontribusi Penginderaan Jauh dan SIG untuk Penanganan Masalah Kesehatan). Disampaikan pada SEMNAS PJ UGM. Yogyakarta.

[2] Depkes RI 2008. Pencegahan dan Pemberantasan Demam Berdarah Dengue di Indonesia. Direktorat Jenderal Pengendalian Penyakit dan Penyehatan Lingkungan. Jakarta.

[3] Firri, Jb. 2013. Survey Jentik Nyamuk Aedes Aegypti dan Indeks Perhitungan. Word Press. Jombang. From:

(http://firiijb.wordpress.com, diakses 5 Juni 2017).
[4] Holani. 2002. Prediksi Dinamika Penularan Malaria di Wilayah Pegunungan. Word Press. Jombang. From:

(https://firiijb.wordpress.com, diakses 6 Juni 2017).

[5] Kaiser, R, Spiegel,PB, Genderson AK. 2003. The Application of Information System and Global Positioning in Humanitarium Emergencies. Leassons L. Programme Implications and Future Research Disaster.

[6] Lazano,R.D; Rodroguez,MH; Avalia,MH. 2002. Gender Related Family and Aedes aegypti Larval Bleeding Risk in Southern Mexico in SaludPublica de Mexico44 :237242

[7] Litbangkes. 2015. DBD dan Lingkungan. Jakarta. From: (http://www.litbang.kemkes.go.id Lnode/681, diakses 6 Juni 2017)

[8] Peristiowati. 2014. Evaluasi Pemberantasan DBD dengan Metode Spasial GIS dan Identifikasi Tipe Virus Dengue di Kota Kediri. Sekolah Tinggi Ilmu Kesehatan Surya Mitra Husada. Kediri. Kantor Lingkungan Hidup Kota Kediri. Kediri.

[9] Riyanto Agus. 2010. Aplikasi Metodologi Penelitian Kesehatan. Nuha Medika. Yogyakarta. 